\title{
Proposition of an Interactive Process Approach in Exploring the Relationship between Corporate Social Responsibility (CSR) Strategy and Perceived CSR: Case of ExxonMobil in Nigeria's Petroleum Industry
}

\author{
Ibe Chidi Michael ${ }^{1}$, Wang Zhi Min ${ }^{1}$, Kwek Choon $\operatorname{Ling}^{2}$ \& Daniel Yii Shiing Kai ${ }^{1}$ \\ ${ }^{1}$ Faculty of Business and Information Science, UCSI University, Kuala Lumpur, Malaysia \\ ${ }^{2}$ Faculty of Accountancy, Business and Finance, UCTAR, Kuala Lumpur, Malaysia \\ Correspondence: Kwek Choon Ling, Faculty of Accountancy, Business and Finance, UCTAR, Kuala Lumpur \\ Campus, Jalan Genting Kelang, Setapak, 53300 Kuala Lumpur, Malaysia. E-mail: kwekcl@acd.tarc.edu.my
}

Received: October 9, 2014

doi:10.5539/ijbm.v10n2p186

\begin{abstract}
Business organizations implement corporate social responsibility (CSR) initiatives with an aim of generating business value. This has often been noted as a means of ensuring sustainable development (SD) in the relationship between business and society. However, some recent cases have produced outcomes that are contrary to this view. This is evident in the Nigerian petroleum industry where multi-national oil companies like ExxonMobil have contributed extensively to their host-communities without generating positive outcomes based on the implemented CSR initiatives. Inspite of their contributions, the stakeholders in their host communities engage in activities that threaten their sustainable development. This outcome reflects a gap in the theory and practice of CSR. This gap was explored through critically examining the case of ExxonMobil with focus on their CSR activities and outcomes. It was revealed that the focus of extant literature on corporate perspective in CSR implementation and the extensive empirical focus on the direct relationship between CSR strategy and perceived CSR lead to a narrow view of the CSR concept. The need to adopt an interactive process approach through looking at the antecedents and outcomes in the relationship between CSR strategy and perceived CSR was proposed as a means of grasping the nature of outcomes generated from CSR.
\end{abstract}

Keywords: corporate social responsibility, perceived CSR, sustainable development, Nigeria Petroleum Industry, proactive CSR, reactive CSR

\section{Introduction}

In 1999, the re-emergence of democracy in Nigeria came with an increased awareness of the impact of corporate practices of businesses on society. This is most visible in the Nigerian petroleum industry. Due to this growing awareness, oil companies like ExxonMobil are increasingly contributing to the communities within which they operate in Nigeria (Ibok \& Mboho, 2011; Mbat, Ibok, \& Daniel, 2013). It reflects in their adoption of annual sustainability reporting practice as a means of showcasing their adherence to social responsibility principles. They implement this through embarking on extensive corporate social responsibility (CSR) initiatives.

However, the increase in conflict between these multi-national oil companies and their host communities in Nigeria is contradictory to the enormous claims of societal contributions that they make. This is evident in the fact that the stakeholders in their host-communities frequently embark on violent activities like protests, riots, blockades, militancy, sabotage among others, which threatens their sustainability (Paki \& Ebienfa, 2011). This has raised questions about the true impact of these oil companies' CSR initiatives on their host-communities (Omotola, 2006; Jike, 2004). This paper is aimed at understanding and proposing solutions to this problem. In doing this, a case study of ExxonMobil is focused on and the exploration of the issue in theory and practice is carried out.

Theoretically, it has been argued that beneath the implementation of CSR initiatives are strategies that can be deployed by companies as means of attaining business benefits (Agle, Mitchell, \& Sonnenfeld, 1999; Porter \& Kramer, 2009). These strategies are called CSR strategies (Groza, Pronschinske, \& Walker, 2011). However, the 
effectiveness of these CSR strategies is dependent upon the extent to which benefits are perceived from CSR initiatives by stakeholders (Groza et al., 2011; Porter \& Kramer, 2009; Claydon, 2011; Bhattacharya et al., 2009). This is referred to as perceived CSR. The focus of this paper is on understanding the means through which CSR strategies translate to perceived CSR as a means of exploring the research problem.

In exploring the relationship between CSR strategy and perceived CSR, extant literature is focused on a direct effect perspective. It has been noted that there are antecedents and consequences attached to CSR activities which determine the nature of interaction between business and society (Stanaland, Lwin, \& Murphy, 2011). These antecedents and consequences make up the process of interaction between business and society, which is referred to as interactive process. The direct effect perspective, which extant studies dwell on, ignores this interactive process perspective. Therefore, it is posited here that the lack of adequate understanding of the interactive process perspective can explain the negative outcomes generated from the implementation of CSR theories in practice. In this paper, a case for the adoption of the interactive process a perspective in the study of the relationship between CSR strategy and perceived CSR is made. In doing this, it is posited that the means of ensuring a value alignment between business and society in the implementation of CSR can be attained, and the means of generating positive outcome from CSR can be better understood.

\section{Corporate Social Responsibility Strategy}

When business decides to implement corporate social responsibility (CSR), there are normally some values that they hope to attain (Porter \& Kramer, 2006). These values are either tangible or intangible (Turban \& Greening, 1997). Tangible values are in the form of financial values, while intangible values are in the form of enhanced reputation and image (Turban \& Greening, 1997), as well as improved trust and loyalty (Stanaland, Lwin, \& Murphy, 2011). In order to provide these tangible and intangible values, these values must also be available for stakeholders (Bhattacharya et al., 2009). Clarkson (1995) noted that it is companies' ability to satisfy stakeholders' demands that determines their survivability and competitiveness. To achieve this, companies roll out effective means of understanding the specific needs and yearnings of stakeholders, which they aggressively respond to through CSR strategies (Agle, Mitchell, \& Sonnenfeld, 1999). The understanding of the specific needs of stakeholders reflects in the form of the choice on how companies should implement their CSR strategies.

In the extant literature, some of the core concepts that have emerged to explain the way CSR strategy is implemented are reactive, defensive, accommodative and proactive implementation of CSR strategy (Wilson, 1975). These means of implementing CSR strategy make up the core concepts of the role of timing in the implementation of CSR strategy. The differences between these concepts are reflected in how CSR strategy is implemented by companies. When a company carves out a CSR strategy that puts it in a position to escape the responsibility that comes with the negative outcomes of its function and existence in society, it employs a reactive strategy (Carroll, 1979, 1999). What this means is that the company seeks to find its way out of the consequences rather than facing it. However, some companies utilize CSR strategies to ensure that the existing legal and ethical frameworks protect them against taking responsibility for the consequences of their activities and functions in society. This is referred to as the defensive CSR strategy (Carroll, 1979, 1999). Companies with this type of CSR strategy take up the shield in the form of the legal establishments or existing laws to defend themselves against embarking on extensive CSR.

Some other companies do not escape from the responsibility that comes with the outcome of their functions and activities in society. However, they need to feel the pressures from the stakeholders before implementing CSR initiatives. These companies employ an accommodative CSR strategy (Carroll, 1979; 1999). These companies respond for strategic reasons that include the maintenance of stability and status quo which are fundamental to the sustainability of their companies. There is a set of companies that actually embark on the implementation of CSR activities without being pressurized or without the occurrence of negative trends. These companies employ a proactive CSR strategy (Carroll, 1979, 1999).

The strategies identified above make up the initial concepts that represent CSR strategies. However, it has been noted that irrespective of the objective underlying a company's aim to implement CSR initiatives, they must fall into the two broad categories of reactive and proactive strategies (Groza et al., 2011). In these two broad categories, reactive implementation of CSR strategy implies the implementation of CSR strategy in a way that makes companies to respond to the occurrence of negative trends in the course of their functions or activities, while proactive strategy implies the implementation of CSR strategy in a way that is not necessarily connected to the occurrence of negative trends or pressures, with the aim of instilling value (Groza et al., 2011). These two broad concepts of CSR strategy are explained further to reveal their implications to CSR implementation. 


\section{Proactive vs. Reactive Corporate Social Responsibility (CSR) Strategies}

Proactive CSR strategy is the implementation of CSR by companies as a mean of instilling value without the occurrence of negative events, while reactive CSR strategy is the implementation of CSR as a mean of instilling value in the face of the occurrence of negative events that are caused by the activities of a company (Groza et al., 2011). It has been found that when companies implement CSR reactively, they are perceived by stakeholders to be serving business goals, but when they implement CSR proactively, they are perceived by stakeholders as adding altruistic value in society (Groza et al., 2011, Ellen, Mohr, \& Webb, 200; Becker-Olsen, Andrew, \& Hill, 2006).

Hill and Becker-Olsen (2005) found that proactive and reactive implementation of CSR programs serve as informational cues that determine the evaluation of CSR programs. Based on the result of their study, they noted that while respondents rated reactive CSR programs negatively, they rated proactive CSR programs positively because they perceived the reactive CSR program to be self-serving, while the proactive CSR program was perceived to be value based. In another study, Becker-Olsen, Cudmore and Hill (2006) found that proactive based CSR program resulted in more favourable attitudes, while the reactive based program resulted in negative thoughts and intentions. Moreover, it has been extensively posited that proactive CSR strategy is widely perceived by stakeholders as responsible business practices that entails businesses contributing to society beyond the standards required of them (Groza et al., 2011). On the other hand, reactive strategy is perceived as a face saving strategy that is aimed at attaining business aims. As a result, proactive implementation of CSR is argued to generate positive response over the reactive implementation of CSR (Groza et al., 2011).

However, it has been noted that outcomes from the implementation of CSR strategies are not assured (Bhattacharya et al., 2009). This is because it has been noted that CSR is context specific, hence dependent upon the context within which it is implemented (Freeman \& Hasnaoui, 2011; Gjolberg, 2009). As a result, this paper examined CSR strategy in the context of the Nigerian petroleum industry. A case study of ExxonMobil is used to see the effects of proactive and reactive CSR strategies on the outcomes generated from the implementation of CSR.

\subsection{Nigeria's Petroleum Industry}

Nigeria's major natural resource, crude oil, was found in the Niger Delta region in 1956. The industry attracted many established multi-national oil companies like Shell, ExxonMobil, Total, and Chevron to name a few. By the 1970s, oil production and export by these companies had become the major source of income in Nigeria's monotonous economy (Davis, 2009). Due to the complexity involved in trying to focus on all the oil companies in Nigeria, this study is narrowed down to ExxonMobil in order to capture a distinct nature of the implementation of CSR by Oil Companies. ExxonMobil is a representative case considering that it is the second largest oil producing company in Nigeria, and is also renowned for implementing CSR initiatives.

\subsection{Case of CSR by ExxonMobil in Nigeria}

Like many of the Oil Companies in Nigeria, ExxonMobil ventured into the petroleum industry for profit. The company started operations in Nigeria in 1955 as Mobil Exploration Nigeria Incorporated (MENI), a year before Shell D'Arcy (Now Shell Petroleum Development Company of Nigeria) successfully drilled oil at Oloibiri. MENI made the first discovery of oil in 1964 (Ibok \& Mboho, 2011). In 1969, the company was transformed into Mobil Producing Nigeria (MPN), and started oil production at Idoho field on the $15^{\text {th }}$ of January, 1970 (NNPC, 2013). By 1971, it commissioned Qua Iboe Terminal (Q. I. T) at Ibeno area of Akwa Ibom State and by 1985, it hit its first million barrel benchmark in oil production (Ibok \& Mboho, 2011). In 1999, Exxon and Mobil merged to become ExxonMobil (Schweitzer, Salmeen, \& Low, 2010). At the moment, it is the second biggest producers of oil in Nigeria after Shell (NNPC, 2013).

In the course of its operations, ExxonMobil has contributed enormously to the societies within which it operates. It embarks on sustainable development through contributing extensively by providing social, economic and environmental values to the society.

ExxonMobil is renowned for its social contribution to its host communities (Mbat, Ibok, \& Daniel, 2013). The most noticeable sign of this can be seen in its provision of pipeborne water, rural electrification initiatives, construction of schools and hospitals among other things (Ibok \& Mboho, 2011). In addition, the company devoted over $\$ 15$ million dollars to tackling Malaria problems in Nigeria and annually awards scholarship to over 500 Nigerian students in collaboration with the Nigerian National Petroleum Corporation (NNPC, 2013). In the area of community development, ExxonMobil has established several initiatives like the Women Economic Opportunity (WEO) initiative, where $\$ 38$ million has been invested, and from where smaller initiatives like 
Global Women in Management (GWIM) has emerged to give women more control of economic resources. For the youths, Graduate Assistance Programs (GAP) has been established to improve the employability and entrepereneurial capacity of the unemployed youths in its host communities.

ExxonMobil has also ensured the economic upliftment of the areas within which it operates. In terms of society, ExxonMobil, along with other oil companies, contribute to $95 \%$ of foreign exchange earnings and $85 \%$ of local revenue earnings in Nigeria (Bitrus, 2011; Edoho, 2008). This is in addition to playing a big part, as the second largest oil producing company in the country, to the $40 \%$ contribution of oil companies to the GDP of the nation (Edoho, 2008).

At the local community level, ExxonMobil is known to adopt a favourable employment policy for qualified indigenes of the host communities within which it operates to improve their wage rate and economic enhancement. The lack of adequately qualified indigenes proved to be an issue initially, but ExxonMobil made sure that stakeholders in the community benefited from the employment benefits in its communities by offering training and development programs. This was done through technical training centres, where the indigenes are absorbed, trained and employed (ExxonMobil Sustainability Report, 2012). By employing indigenes, income is provided, which enhances the livelihood of the members of the host communities, and alleviates the effects of their loss of their traditional means of livelihood.

ExxonMobil has also experienced growth in its profits. In the first quarter of 2013, the company saw strong global earnings of $\$ 9.5$ billion. However, the profits from its Nigerian operations have considerably slowed down due to disruptions that caused a crash in its production capacity. This was so severe that ExxonMobil suffered a loss of over 1 million barrels of crude oil in November, 2012, which was caused by the sabotage of its pipelines (Daily Independent Nigeria, 2012). This sabotage resulted in oil spills and translated into further financial losses in the form of compensation to community and employment of over 500 local personnel for clean up efforts (Daily Independent Nigeria, 2012).

Environmental protection is embedded within the fabrics of the policy of ExxonMobil in Nigeria. This is in line with the propositions by scholars in CSR (Wartick \& Cochran, 1985;Wood, 1991). The company has a policy framework that supports the prevention of incidents, control of emissions and wastes, conduct of research and development activities to enhance understanding of the impact of business on society, communication with public on environmental matters and fostering of evaluation efforts to implement compliance to its environmental policies (ExxonMobil Sustainability Report, 2012). These policies are followed by actions.

The actions are reflected in its efforts in trying to stop the occurrence of oil spills. This has been followed by actions like the adoption of technologically enhanced processes in the form of testing gas wells directly to sales lines in place of flaring them into the atmosphere to lower the extent of carbon emission (ExxonMobil Sustainability Report, 2012). This, among other techniques, are proactive strategies that are aimed at sustaining the environment while production is being sustained.

There have been cases when ExxonMobil was caught unawares. In these cases, the negative impact of ExxonMobil's operations occur unexpectedly. The company has proven to react effectively to contain the negative effects of the oil spills in its host communities (Aghalino \& Eyinla, 2009). Apart from spending millions of dollars in responding to these negative trends from its production activities, the oil company joined a responsive organization like the Clean Nigeria Associates (CNA), which was established in 1981 to pool resources together for a faster response to negative environmental outcomes from production activities. In addition, the company works closely with the national oil spill detection and response Agency (NOSDRA) and its host-state's department of petroleum resources (DPR) to tackle such unexpected occurences. More still, in such cases, compensations are paid to host communities to alleviate the consequences of these negative environmental occurences (Aghalino \& Eyinla, 2009).

\subsection{Outcomes from ExxonMobil's CSR}

Despite the implementation of CSR initiatives by ExxonMobil, the company is always in conflict with the stakeholders in its host communities (Omotola, 2006). On the $15^{\text {th }}$ of November, 2010, one of the ExxonMobil's gas and condensate complexes was viciously attacked and set alight before 8 employees of the company were kidnapped (Vanguard Newspaper Nigeria, 2012). Also, 2000 youths from their host community blocked the access road to Qua Iboe Terminal (Q.I.T) to protest the perceived continuous negligence by ExxonMobil, thereby disrupting the production operations of the company (Vanguard Newspaper Nigeria, 2012).

In late 2013, the youths of Eket and Ibeno local government areas embarked on week of protest to make the oil company to pay compensation for an oil spill that occurred in 2012, thereby blocking the operations of the 
company for the duration of the protest, which led to losses on the part of the company (Thisday Newspaper Nigeria, 2013). All these occurrences disrupt the production capacity of ExxonMobil, which declined by 1.7 million in 2009 (Paki \& Ebienfa, 2011) and 1 million in late 2012 (Daily Independent Newspaper, 2012). For example, ExxonMobil had to declare a force majeure in November, 2012 by shutting down production due to leaks from a pipeline which affected its ability to meet projected lifting of petroleum products (Vanguard Newspaper Nigeria, 2012). Government agencies and company authorities revealed that the leak was due to sabotage from the nefarious activities of stakeholders in its host communities, whose intentions was perceived as being to seek for compensations (Vanguard Newspaper Nigeria, 2012).

These losses are not specific to ExxonMobil. They reflect in the oil industry in general. the enormity of the effect of these negative activities by the stakeholders in the host communities of oil companies in Nigeria, over the years, has increased the losses suffered by these oil companies (Omotola, 2006).

From the outcome generated above, it can be deduced that the use of proactive and reactive CSR strategy in the implementation of CSR initiatives by ExxonMobil is evidently not resulting to positive outcomes, hence constitutes a threat to the sustainability of business and society in the industry. This challenges the theoretical argument by scholars about the generation of positive outcome from the perception of CSR when it is proactively implemented. As was noted Bhattacharya et al. (2009), situational dynamics actually render companies' strategic plans obsolete and cause changes in the expectations of stakeholders. Also, that returns from CSR is everything but assured. So, it is important to re-evaluate how stakeholders perceive strategic proactivity by companies in implementing CSR initiatives so as to understand the reasons behind the outcomes generated.

\subsection{Perceived Corporate Social Responsibility}

Perceived CSR has two perspectives. The first perspective describes it in terms of stakeholders' evaluation of CSR initiatives according to how much they attained the objectives that they were implemented for, while the second perspective describes perceived CSR in terms of the attributions about the motives behind the establishment of CSR initiatives by companies (Bhattacharya et al, 2009). While ExxonMobil has been shown to have implemented most of its CSR initiatives (Aghalino \& Eyinla, 2009; Ibok \& Iboho, 2011), the nature of attribution made by its stakeholders about the implementation of CSR has not been focused on. In the context of this research, stakeholders go beyond evaluating the implementation of CSR to perceive that there are motives behind the establishment of CSR initiatives. Through the perception of these motives, the reasons for the nature of outcomes generated can be understood (Bhattacharya et al., 2009).

In perceiving CSR, stakeholders tend to elaborate messages and assign types of motives to businesses when presented with evidence of their social involvement. This is referred to as attribution. This elaboration of messages and assignment of motives by stakeholders clearly shows that the successful implementation of CSR by companies is not an end in itself. Efforts should be made to understand the motives ascribed by stakeholders to the implementation of these CSR initiatives (Hill \& Becker-Olsen, 2005).

This paper views perceived CSR of stakeholders from the perspective of how they make attributions about the implementation of CSR initiatives. It is rotted in the foundation of the attribution theory. The study of perceived cause of an event is the root of the attribution theory (Kelley \& Michela, 1980). In general, this theory is concerned with how individuals interpret events and how this relates to their thinking and behaviour (Weiner, 1974, 1986). Attribution theory assumes that people try to determine why people do what they do. A person seeking to understand why another person did something may attribute one or more causes to that behaviour (Heider, 1958; Kim \& Lee, 2012). The nature of attribution made by stakeholders plays a part in how outcomes are generated from the CSR strategy employed by company. This has been empirically studied.

\subsection{CSR Strategy and Perceived CSR Studies}

It has been widely posited that CSR initiatives that are implemented without the occurrence of negative events are attributed as being value adding by stakeholders. In empirical studies, this has been proven. Ricks (2005) found that targeted respondents perceived proactive contribution to society higher on the evaluation of corporate associations, brand evaluation and patronage intentions. Groza et al. (2011) also found that when CSR strategy is proactively implemented by company, value-driven attributes are generated in which produces positive response from stakeholders. Hill \& Becker-Olsen (2005) found that respondents perceived reactive motivated CSR programs negatively and proactive motivated CSR programs positively, a finding that they ascribed to the timing of implementation of CSR strategies and the nature of stakeholders' attribution about companies' goals for implementing CSR. 
However, some findings have also shown that situation plays a part in stakeholders' attribution. For example, Ellen et al. (2000) found that respondents donated more to disaster relief CSR programs that are reactive in nature than to on-going ones that are proactive in nature. In this case, reactive implementation of CSR strategy is seen as being value-driven while proactive implementation of CSR strategy was viewed as being strategy-driven. This is made complicated by the recent events in the Nigerian petroleum industry, where Oil Companies also employ proactive strategy in the implementation of CSR but their stakeholders still seem not to positively perceive their CSR initiatives (Opukri \& Ibaba, 2008; Aghalino \& Eyinla, 2009). As a result of this outcome, it has become important to re-evaluate how stakeholders perceive CSR, especially with regards to the strategy employed by companies in the implementation of CSR.

The need to understand and balance the interests of business and society in a way that they will be sustainable and non-disruptive to each other is urgently needed. Though, the study of this balance has extensively produced models in extant studies (Carroll, 1979; 1999; Aras \& Crowther, 2009; Claydon, 2011), there is still a gap in the understanding of the interactive process through which this balance is ensured from the implementation to the generation of outcome from CSR (Bhattacharya et al., 2009; Walker, Heere, Parent, \& Drane, 2010). This is mostly blamed on the focus of studies on how CSR strategies affect perceived CSR, without studies devoted to the process through which this relationship translates into outcome (Bhattacharya et al., 2009; Walker et al., 2010). This is referred to here as interactive process. An interactive process approach in the study of the relationship between CSR strategy and perceived CSR is proposed in this paper.

\subsection{Case for Interactive Process Approach}

The need for the study of CSR in a way that will aid the grasping of the interaction effects that influences the relationship between business and society (Walker et al., 2010) and at the same time enhances an understanding of the underlying process that drives the generation of returns from CSR (Bhattacharya et al., 2009) has been addressed and recommended in extant literature. The interactive process simply denotes the process of interaction between business and society (Bhattacharya et al., 2009). In CSR, it implies going beyond the prescriptive and normative nature of the view about the implementation of CSR to explore the process through which performance is generated. In other words, it means looking beyond current practice to assess the means through which outcomes are attained. In doing this, Bhattacharya et al. (2009) noted that exploring both the corporate and stakeholders' perspective is needed. This will require a shift from the predominant corporate view of CSR in the extant literature, to a more balanced view between business and society.

As was noted earlier, recent studies have suggested that the nature of the implementation of CSR has an effect on the stakeholders' perception of the motives behind companies' decision to implement CSR (Ellen, Mohr, \& Webb, 2000; Hill \& Becker-Olsen, 2005; Kim \& Lee, 2012). This means that the determination of the outcome derived from the implementation of CSR is dependent upon what stakeholders attribute as the reason behind such an implementation. This view vindicates the calls for an exploration of both the companies' and stakeholders' views. Invariably, companies' implementation of CSR does not guarantee the nature of outcome to be derived. Rather, the nature of attribution ascribed to the implementation by stakeholders is vital towards determining the nature of outcomes generated from CSR.

Some recent studies have attempted to explore the nature of stakeholders' attribution to the implementation of CSR (Ellen et al., 2000; Baden, Meyer \& Tonne, 2011; Groza et al., 2011; Du, Bhattacharya, \& Sen, 2007). These studies intended to explore the nature of stakeholders' attribution about the strategy employed by company in the implementation of CSR. This paper is recommending the same focus as these extant studies; however, an interactive process approach is proposed and added in the study.

\subsection{Implementation of an Interactive Process Approach in Research}

Implementing an interactive process requires looking at important antecedents and outcomes that determine the nature of relationship between CSR strategy and perceived CSR. While a direct relationship has been extensively explored, these antecedents and outcomes are yet to be determined. For example, Bhattacharya et al (2009) noted that the value perceived by stakeholders from the implementation of CSR is an important antecedent in the recognition of the usefulness and importance of CSR initiatives that were implemented by companies. This is a vital observation.

In the case study, it could be observed that a vital issue in the strife between ExxonMobil and its community stakeholders is lack of perception of value from its implementation of CSR. This is evident in the fact that the Oil Company has been proven to have instilled socio-economic and environmental values in its host-communities (Mbat, Ibok, \& Daniel, 2013; Ibok \& Mboho, 2011), but these contributions are not ensuring the sustainability of business and society. Sustainability of business and society reflects in the form of 
contributions of business to the social, economic and environmental sustenance of society, and a reciprocal sustenance of business through a cordial and supportive relationship with society (Claydon, 2011). This is obviously not the case in ExxonMobil's case. As a result, when exploring the relationship between ExxonMobil and its host-communities' stakeholders, it will be inadequate to look at a direct relationship between the CSR strategy employed by the Oil Company and the perceived value of its community stakeholders. It will be more effective to take an interactive process approach.

The implementation of an interactive process in ExxonMobil's case study will imply exploring the antecedents and outcomes to the relationship between the CSR strategies employed by the company and perceived CSR. Since perceived value is an important antecedent and outcome in the attributions formed by stakeholders, as noted by Bhattacharya et al. (2009), perceived value could be explored as an antecedent, outcome and mediator of the relationship between CSR strategy and perceived CSR. This reflects the interactive process approach. To do this, the means through which business claims to instil value in the society should be tested against the perception of such value by stakeholders. In doing this, the true impact of the CSR strategy employed by business will be seen in perceived value as an outcome, and the nature of perceived value can be viewed as an antecedent to the perception of CSR.

In the case of ExxonMobil, the Oil Company claims to instil value through implementing CSR by adhering to the principles of the triple bottom line (TBL) (ExxonMobil Sustainability Report, 2012). Also, it has been shown that it does this through employing both proactive and reactive CSR strategies (Ibok \& Mboho, 2011). In order to explore the true impact of these value claims, it is important to explore the nature of value perceived by the stakeholders in its host-communities, and also explore if the nature of perceived values generated has an impact on the nature of their perception of CSR. In doing this, the reasons behind the non-perception of CSR can be deduced, and the potential solutions can be proffered.

\section{Recommendations for Future Research}

As can be seen in this paper, there is an obvious gap between the theoretical propositions made about the relationship between CSR strategy and perceived CSR, and the outcome generated in practice. Even though it has been widely posited that the implementation of proactive and reactive CSR strategies generated differing outcomes, the antecedents of these outcomes are yet to be determined. This paper has made some recommendations that will aid research towards determining these outcomes.

First, it is important for more researchers to take an interactive process approach in trying to determine the nature of outcome from the implementation of CSR. It has been noted that exploring the impact of CSR strategy is simply not enough. There is need to go further to explore the interaction process as proposed by Bhattacharya et al. (2009) and Walker et al. (2010). This interaction process should be aimed at exploring antecedents and outcomes to the relationship between the CSR strategies employed by company and the perceived CSR of the stakeholders in its host communities.

Secondly, it is recommended that research should go beyond the corporate view in exploring the relationship between CSR strategy and perceived CSR. This will require exploring both companies' and stakeholders' perspectives. This means that efforts should be exerted towards exploring stakeholders' perception in tandem with companies' implementation of CSR. This is because it has been noted that stakeholders are increasingly becoming influential to corporate decisions and strategies employed by companies (Garriga \& Mele, 2004). In addition, their views will provide further understanding of the nature of their attribution and response to companies' CSR strategies.

Thirdly, it is recommended that more efforts should be directed towards exploring the relationship between CSR strategy and perceived CSR through employing statistical methods that can handle complex relationships. Most of the studies about the relationship between CSR strategy and perceived CSR are explored as direct relationships (Ellen, Mohr, \& Webb, 2000; Hill \& Becker-Olsen, 2005; Kim \& Lee, 2012), which requires the use of simple statistical methods. By exploring the interactive process in the relationship, a more complex statistical method will be needed to effectively handle the direct, mediating and moderating relationships.

\section{Conclusion}

The nature of the relationship between CSR strategy and perceived CSR was explored through a case study of ExxonMobil in the Nigerian petroleum industry. The analysis carried out reflected the enormous contributions that have been made by the oil company. However, these contributions have not enhanced the relationship between ExxonMobil and their host-communities in Nigeria. This can be seen from the increasing threat that their stakeholders pose to their sustainability. This problem formed the foundation of this paper. 
To explore this problem, a literature review was carried out. It was identified that understanding the relationship between the CSR strategy used by a business and the nature of perception of CSR initiatives by stakeholders is vital in finding out the nature of outcomes from the implementation of CSR. It was also noted that even though some studies have focused on this relationship, they do this from a narrow perspective of the direct impact of CSR strategy on perceived CSR. It is posited that this narrow view can be expanded through exploring the antecedents and outcomes that define the relationship between CSR strategy and perceived CSR, which is known as an interactive process perspective.

Applying the interactive process perspective to ExxonMobil's case study implies the need for a re-orientation in the approach being used by multi-national oil companies in Nigeria. This re-orientation requires a shift from their current corporate dominant focus, to a combined corporate and stakeholders' focus in the implementation of CSR. What this means is that oil companies like ExxonMobil will need to explore and understand the value expectations of their host-communities, and implement CSR initiatives based on this understanding in order to ensure that their contributions are perceived by their stakeholders. It was recommended that this should be backed up by theoretical extensions through exploring moderators, mediators and control variables in the relationship between CSR strategy and perceived CSR. In addition, adoption of more advanced statistical analysis techniques was recommended in exploring the complex relationships that will emerge.

This paper succeeded in creating an understanding of the nature of the relationship between multi-national oil companies in Nigeria and their host-communities through the case study of ExxonMobil. A proposition of an interactive process perspective was made as a solution to the research problem. A major weakness in this paper is in the lack of description of how the interactive process should be precisely implemented. This is due to the limited scope of this paper. However, the nature of perceived value of stakeholders was introduced as a possible mediator in the relationship between CSR strategy and perceived CSR. More importantly, the recommendations that were made will aid theoretical expansion of focus in the study of the relationship between CSR strategy and perceived CSR. This will inevitably lead to the generation of mediators, moderators and control variables that will define the precise nature of the recommended interactive process.

\section{References}

Aghalino, S. O., \& Eyinla, B. (2009). Oil Exploration and Marine Pollution: Evidence from the Niger Delta, Nigeria. Journal of Human Ecology, 28(3), 177-182.

Agle, B. R., Mitchell, R. K., \& Sonnenfeld, J. A. (1999). What Matters to CEOs? An Investigation of Stakeholder Attributes and Salience. Corporate Performance, and CEO Values, 42, 507-525.

Aras, G., \& Crowther, D. (2009). Corporate Sustainability Reporting: A Study in Disingenuity. Journal of Business Ethics, 87(1), 279-288. http://dx.doi.org/10.1007/s10551-008-9806-0

Baden, D., Meyer, E., \& Tonne, M. (2011). Which Types of Strategic Corporate Philanthropy Lead to Higher Moral Capital? Proceedings of the Twenty-Second Annual Conference of the International Association for Business and Society, 12.

Becker-Olsen, K. L., Andrew, B., \& Hill, R. P. (2006). The Impact of Perceived Corporate Social Responsibility on Consumer Behaviour. Journal of Business Research, 59(1), 46-53. http://dx.doi.org/10.1016/j.jbusres.2005.01.001

Bhattacharya, C. B., Korschun, D., \& Sen, S. (2009). Strengthening Stakeholder-Company Relations through Mutually Beneficial Corporate Social Responsibility Initiatives. Journal of Business Ethics, 85(2), 257-272. http://dx.doi.org/10.1007/s10551-008-9730-3

Bitrus, Y. P. (2011). Global Financial Crisis and Oil Revenue in Nigeria. Journal of Economics and Sustainable Development, 2(5), 1-18.

Carroll, B. A. (1979). A Three Dimensional Conceptual Model of Corporate Performance. Academy of Management Review, 4(4), 497-505. http://dx.doi.org/10.5465/AMR.1979.4498296

Carroll, A. B. (1999). Corporate Social Responsibility. Business and Society, 38(3), 268-295. http://dx.doi.org/10.1177/000765039903800303

Claydon, J. (2009). Two Models of CSR and Sustainability: A comparison between the Pyramid of Corporate Social Responsibility and the Model of Sustainable Development. Issues in Social and Environmental Accounting, 2(2), 260-265.

Daily Independent Newspaper Nigeria. (2012). Nigeria's Oil Production Drop Below $1.5 \mathrm{~m}$ bpd. Retrieved $5^{\text {th }}$ June, 2013 from http://dailyindependentnig.com/2012/11/nigerias-oil-production-drops-below-1-5m-bpd/ 
Davis, S. (2009). The Opportunity for Peace in the Niger Delta. GEEI Green Paper Series, 2.

Edoho, F. M. (2008). Oil Transnational Corporations: Corporate Social Responsibility and Environmental Sustainability. Corporate Social Responsibility and Environmental Management, 15(4). 210-222. http://dx.doi.org/10.1002/csr.143

Ellen, P. S., Mohr, A. L., \& Webb, J. D. (2000). Charitable Programs and the Retailer: Do They Mix? Journal of Retailing, 76(3), 393-406. http://dx.doi.org/10.1016/S0022-4359(00)00032-4

ExxonMobil Corporate Citizenship Report. (2012). Retrieved July $18^{\text {th }}$, 2013 from http://cdn.exxonmobil.com/ /media/Reports/Corporate\%20Citizenship\%20Report/2012/news_pub_ccr2012 .pdf

Freeman, I., \& Hasnaoui, A. (2011). The Meaning of Corporate Social Responsibility: The Vision of Four Nations. Journal of Business Ethics, 11, 419-443. http://dx.doi.org/10.1007/s10551-010-0688-6

Garriga, E., \& Mele, D. (2004). Corporate Social Responsibility Theories: Mapping the Territory. Journal of Business Ethics, 53, 51-71. http://dx.doi.org/10.1023/B:BUSI.0000039399.90587.34

Gjolberg, M. (2009). Measuring the Immeasurable? Constructing an Index of CSR Practices and CSR Performance in 20 countries. Scandinavian Journal of Management, 25, 10-12.

Groza, D. M, Pronschinske, R. M., \& Walker, M. (2011). Perceived Organizational Motives and Consumer Responses to Proactive and Reactive CSR. Journal of Business Ethics, 102, 639-652. http://dx.doi.org/10.1007/s10551-011-0834-9

Heider, F. (1958). The Psychology of Interpersonal Relations. NY: Wiley. http://dx.doi.org/10.1037/10628-000

Hill, R., \& Becker-Olsen, K. L. (2005). The Impact of Perceived Corporate Social Responsibility On Consumer Behavior. E-Scholarship. UC Berkley: Centre for Responsible Business.

Ibok, E. E., \& Mboho, K. S. (2011). Corporate Social Responsibility Towards Host-Communities in Nigeria: Focus on ExxonMobil in Akwa Ibom State. Journal of Sociology, Psychology and Anthropology in Practice, 3(1), 110-119.

Jike, V. T. (2004). Environmental Degradation, Social Disequilibrium, and the Dilemma of Sustainable Development in the Niger-Delta of Nigeria. Journal of Black Studies, 34(5), 686-701. http://dx.doi.org/10.1177/0021934703261934

Kelley, H. H., \& Michela, J. L. (1980). Attribution Theory and Research. Annual Review of Psychology, 31, 457-501. http://dx.doi.org/10.1146/annurev.ps.31.020180.002325

Kim, S., \& Lee, Y. J. (2012). The Complex Attribution Process of CSR Motives. Public Relations Review, 38(1), 168-170. http://dx.doi.org/10.1016/j.pubrev.2011.09.024

Mbat, D., Ibok, E., \& Daniel, E. (2013). ExxonMobil and Corporate Social Responsibility in Akwa Ibom State, Nigeria: Past and Present. Public Policy and Administration Research, 3(3), 21-29.

Nigerian National Petroleum Corporation. (2013). History of the Nigerian Petroleum Industry. Retrieved $15^{\text {th }}$ June, 2013 from http://www.nnpcgroup.com/NNPCBusiness/BusinessInformation/OilGasinNigeria/IndustryHistory.aspx

Omotola, J. S. (2006). The Next Gulf? Oil Politics, Environmental Apocalypse and Rising Tension in the Niger Delta. Accord Occasional Paper Series, 1(3), 3-31.

Opukri, C. O., \& Ibaba, S. I. (2008). Oil Induced Environmental Degradation and Internal Population Dispalcement in the Nigeria's Niger-Delta. Journal of Sustainable Development in Africa, 10(1), 173-193.

Porter, M. E., \& Kramer, M. R. (2006). Strategy \& Society: The Link between Competitive Advantage and Corporate Social Responsibility. Harvard Business Review, 84(12), 78-92.

Ricks, J. M. (2005). An Assessment of Strategic Corporate Philanthropy on Perceptions of Brand Equity Variables. Journal of Consumer Marketing, 121-134. http://dx.doi.org/10.1108/07363760510595940

Schweitzer, D., Salmeen, I., \& Low, B. (2010). Oil Companies and Sustainability: Just an Image? In

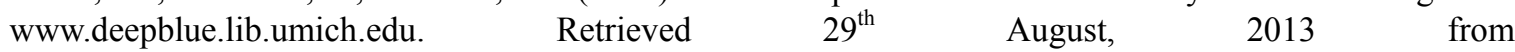
http://deepblue.lib.umich.edu/bitstream/handle/2027.42/77607/dschwei.pdf

Stanaland, A. J. S., Lwin, M. O., \& Murphy, P. E. (2011). Consumer Perceptions of the Antecedents and Consequences of Corporate Social Responsibility. Journal of Business Ethics, 102, 47-55. 
http://dx.doi.org/10.1007/s10551-011-0904-z

Vanguard. (2012). Oil Leak: ExxonMobil Shuts in Production. Retrieved 18th August, 2012 from http://www.vanguardngr.com/2012/11/oil-leak-exxonmobil-shuts-in-production/

Turban, D. B., \& Greening, D. W. (1997). Corporate Social Performance and Organizational Attractiveness to Prospective Employees. Academy of Management Journal, 40, 658-672. http://dx.doi.org/10.2307/257057

Walker, M., Heere, B., Parent, M. M., \& Drane, D. (2010). Social Responsibility and the Olympic Games: the Mediating Role of Consumer Attributions. Journal of Business Ethics, 95, 659-680. http://dx.doi.org/10.1007/s10551-010-0445-x

Wartick, S. L., \& Cochran, P. (1985). The evolution of the Corporate Social Performance model. The Academy of Management Review, 10(4), 758-769. http://dx.doi.org/10.5465/AMR.1985.4279099

Weiner, B. (1986). An Attributional Theory of Motivation and Emotion. NY: Springer Verlag. http://dx.doi.org/10.1007/978-1-4612-4948-1

Wilson, I. (1975). What One Company is Doing About Today's Demands on Business. In G. A. Steiner (Ed.), Changing Business-Society Interrelations. CA: Graduate School of Management, UCLA.

\section{Copyrights}

Copyright for this article is retained by the author(s), with first publication rights granted to the journal.

This is an open-access article distributed under the terms and conditions of the Creative Commons Attribution license (http://creativecommons.org/licenses/by/3.0/). 